\title{
Intestinal zinc transfer by everted gut sacs from rats given diets containing different amounts and types of dietary fibre
}

\author{
BY C. J.SEAL AND J. C. MATHERS* \\ Department of Agricultural Biochemistry and Nutrition, University of Newcastle upon Tyne, \\ Newcastle upon Tyne NE1 7RU
}

(Received 19 December 1988 - Accepted 3 March 1989)

\begin{abstract}
Two experiments were carried out in which rats were offered diets containing different amounts and types of dietary fibre, i.e. commercial stock diet and three semi-purified diets containing no fibre, $200 \mathrm{~g}$ wheat bran or $200 \mathrm{~g}$ pectin/kg. Dietary inclusion of fibre, and especially pectin, stimulated large bowel fermentation, as indicated by caecal hypertrophy and reduced caecal pH. After 3 weeks, mucosal : serosal zinc transfer and $\mathrm{Zn}$ accumulation by tissue were measured using the everted-gut-sac technique. In Expt 2 , incubations were carried out in the presence and absence of 0.25 mm-ouabain to assess the importance of transfer by $\mathrm{Na}^{+}, \mathrm{K}^{+}$-ATPase-dependent mechanisms, and some observations on glucose transport were also made. Ouabain reduced rates of transfer of both $\mathrm{Zn}$ and glucose and also tissue $\mathrm{Zn}$ accumulation. There were no significant differences in rates of $\mathrm{Zn}$ transfer by everted sacs from duodenal, ileal and colonic sites, but accumulation of $\mathrm{Zn}$ by tissue was a more important fate than transfer across the serosal surface, and accumulation by duodenal tissue was approximately twice as great as by other tissues. Mucosal:serosal transfer of glucose by ileal tissue was much more sensitive to ouabain than was $\mathrm{Zn}$ transfer. Previous diet appeared to alter the capacity of the intestinal tissue to transfer $\mathrm{Zn}$, with the highest rates of transfer being by colonic tissue from pectin-fed rats.
\end{abstract}

Dietary fibre: Zinc: Glucose: Rat.

Zinc is transported across the enterocyte brush-border membrane from the intestinal lumen by a carrier-mediated, saturable process (Cousins, 1986; Solomons, 1986) which may be assisted by binding of the metal to a low-molecular-weight organic ligand such as citrate (Lonnerdal et al. 1980) or 2-picolinate (Evans \& Johnson, 1981; Seal \& Heaton, 1983, 1985). $\mathrm{Zn}$ absorption is under homeostatic regulation and is stimulated by dietary $\mathrm{Zn}$ depletion (Evans et al. 1973; Hoadley et al. 1987). The site(s) of $\mathrm{Zn}$ absorption within the gastrointestinal tract has not been established unequivocally. Whilst Underwood (1977) concluded that 'in rats, zinc is absorbed mainly from the duodenum, ileum and jejunum with very little being absorbed from the stomach and colon' and Davies (1980) found negligible absorption of $\mathrm{Zn}$ from the caecum and colon, others have reported that substantial $\mathrm{Zn}$ absorption may occur in the large intestine of rats (Meneely \& Ghishan, 1982; Ghishan \& Sobo, 1983; Wapnir et al. 1985), pigs (Partridge, 1978), sheep (Grace, 1975) and cattle (Bertoni et al. 1976). Within the small intestine, the relative importance of proximal and distal regions is also controversial.

Consumption of foods rich in dietary fibre (non-starch polysaccharides; NSP) and phytate has been associated with reduced availability of minerals including calcium (McCance \& Widdowson, $1942 a, b$ ) and Zn (O'Dell \& Savage, 1960; Davies \& Nightingale, 1975 ; Davies \& Reid, 1979) in some but not all studies (Fairweather-Tait \& Wright, 1985). The mechanism of this reduced availability is believed to include (1) binding of minerals to NSP components (James et al. 1978) and (2) co-precipitation as $\mathrm{Zn}-\mathrm{Ca}$-phytate complexes (Oberleas et al. 1966) in which forms the minerals are unavailable for absorption. When

* For reprints. 
Table 1. Composition $(\mathrm{g} / \mathrm{kg})$ of semi-purified diets

\begin{tabular}{lccc}
\hline \hline Diet ... & No fibre & + Bran & + Pectin \\
\hline Sucrose & 660 & 498 & 478 \\
Casein & 200 & 162 & 182 \\
Wheat bran & 0 & 200 & 0 \\
Pectin & 0 & 0 & 200 \\
Maize oil & 80 & 80 & 80 \\
Cod-liver oil & 20 & 20 & 20 \\
Salt mixture* & 45.3 & 45.3 & 45.3 \\
Vitamin mixture* & 0.77 & 0.77 & 0.77 \\
\hline
\end{tabular}

* For full details of salt and vitamin mixtures, see Seal \& Heaton (1983)

digesta reach the large bowel they are subject to extensive attack by bacteria which ferment much of the NSP (Cummings, 1981) and hydrolyse phytate (Wise, 1983). There have been suggestions that compensatory absorption of minerals from the large bowel may then follow (Cummings et al. 1979).

The present study was designed to investigate possible effects of giving diets varying in content and type of NSP on the potential for absorption of $\mathrm{Zn}$ by different sites within the small and large intestine of rats. Some observations on glucose transport are also included.

A brief account of part of the present work has been published (Seal \& Mathers, 1987).

\section{MATERIALS AND METHODS}

Expt 1

\section{Animals and diets}

Four diets containing different types and amounts of dietary fibre were used in the study. They included a commercial pelleted rat diet (stock; Oxoid 41B) and three isonitrogenous semi-purified diets based on sucrose and casein (Seal \& Heaton, 1983). The semi-purified diets contained either no added fibre (no-fibre diet), $200 \mathrm{~g}$ wheat bran (+bran; Prewetts, Byfleet, Surrey) $/ \mathrm{kg}$ or $200 \mathrm{~g}$ pectin (+ pectin; $7.7 \%$ methoxy content; Sigma) $/ \mathrm{kg}$. The formulation of the diets is shown in Table 1 . The complex carbohydrate contents $(\mathrm{g} / \mathrm{kg}$ as used) of the stock diet and of the wheat bran used to prepare the + bran diet were respectively: starch 282 and 204, NSP 187 and 370, the monosaccharide components of the NSP being $(\mathrm{mg} / \mathrm{g})$ : rhamnose 1.2 and 2.0 , arabinose 13.2 and $82 \cdot 1$, xylose 65.1 and 147.3 , mannose 0.1 and trace, galactose 3.7 and 3.9 , glucose 99.6 and 125.9 , uronic acids 4.0 and 8.8 respectively. The stock, no fibre, + bran and + pectin diets contained $41,15,30$ and $17 \mu \mathrm{g} \mathrm{Zn/g}$ dry matter (DM) respectively.

Male Wistar albino rats weighing approximately $150 \mathrm{~g}$ were randomly allocated to diets and cages, and were housed in pairs (semi-purifed diets) or groups of three (stock diet only) with six rats per diet. The diets were provided $a d$ lib for 3 weeks before the rats were used for gut sac experiments.

\section{Gut sac incubations}

Rats were killed by cervical dislocation at approximately 11.00 hours and sections of the intestine removed immediately and rinsed free of digesta with physiological saline $(9 \mathrm{~g}$ $\mathrm{NaCl} / 1$ ). Segments of $30-40 \mathrm{~mm}$ length were cut from each region of the intestine. Duodenal segments were taken from the first $120 \mathrm{~mm}$ posterior to the common bile duct and ileal segments from the region immediately anterior to the ileo-caecal junction. Colonic 
segments were taken from the region immediately posterior to its junction with the caecum. The caecum from each rat was also removed and weighed with its contents. Two segments from each region were placed in previously aerated $\mathrm{Zn}$-free Tris-Krebs buffer, $\mathrm{pH} \mathrm{7.3}$ at $37^{\circ}$ (Seal \& Heaton, 1983). A third segment was retained for $\mathrm{Zn}$ analysis. The two segments were everted and filled with $\mathrm{Zn}$-free Tris-Krebs buffer and then incubated for $30 \mathrm{~min}$ in the same buffer containing $20 \mathrm{mg} \mathrm{Zn}$ as zinc sulphate/l. At the end of the incubation period the sacs were rinsed, blotted and the contents and tissue retained for $\mathrm{Zn}$ analysis.

\section{$\operatorname{Expt} 2$}

\section{Effect of ouabain}

Six Wistar rats, initial weight $220 \mathrm{~g}$, were randomly allocated to each of the four diets described previously, except for the group fed on the + bran diet ( $n 4)$, and housed in pairs. Stock diet was fed ad lib., and semi-purified diets were fed at $20 \mathrm{~g} / \mathrm{rat}$ per $\mathrm{d}$ at approximately 16.00 hours daily for $22-28 \mathrm{~d}$ before measurements were made. Sections of gut were removed and everted gut sacs prepared as described previously. One gut sac from each region was incubated in Tris-Krebs buffer containing $20 \mathrm{mg} \mathrm{Zn}$ as $\mathrm{ZnSO}_{4} / 1$ and $11.5 \mathrm{~mm}$-glucose. The second sac was incubated in the same buffer containing $0.25 \mathrm{~mm}$ ouabain. After incubation for $30 \mathrm{~min}$, gut-sac contents and tissues were retained for $\mathrm{Zn}$ analysis. The caecum from each rat was removed, weighed with its contents and the $\mathrm{pH}$ of the contents measured directly with a $\mathrm{pH}$ meter fitted with a glass micro-electrode (Corning, Halstead, Essex).

\section{Analytical methods}

Intestinal sacs and unincubated tissue samples were oven-dried at $65^{\circ}$ to constant weight. Dried sacs and diets were wet ashed for $16 \mathrm{~h}$ at $60^{\circ}$ in a mixture of concentrated nitric, sulphuric and perchloric acids $(3: 3: 1$, by vol.). $\mathrm{Zn}$ was determined in sac contents and wetashed samples using a Pye Unicam SP9 atomic absorption spectrophotometer (Pye Unicam Ltd, Cambridge). Glucose in gut-sac contents was measured enzymically using a YSI 23A Glucose Analyser (Clandon Scientific Ltd, Aldershot, Hants). Complex carbohydrates in foods were determined and characterized by the methods of Englyst \& Cummings (1984, 1985).

\section{Statistical methods}

Values were examined by analysis of variance in which diets were considered as main plots and their effects tested against the between-animals within-diets variance. Sites within the intestine were considered as a sub-plot and the effects of sites and diets $\times$ sites interaction were tested against the between-animals within-diets and sites variance (error 2); see Table 2. A priori-nominated orthogonal contrasts were used to distinguish between diets, between sites and between diets $\times$ sites interactions as indicated in Table 2 . The contrast $\mathrm{S} v$. $(N+B+P)$ compared the value for the stock diet $(S)$ with the mean for the three semipurified diets $(\mathrm{N}, \mathrm{B}$ and $\mathrm{P})$ whilst $\mathrm{N} v \cdot(\mathrm{B}+\mathrm{P})$ compared the no-fibre $\operatorname{diet}(\mathrm{N})$ with the mean for diets containing added fibre $(B$ and $P)$. Similarly, the contrast $(D+I) v$. C compared the mean for the small intestinal sites (D and I) with that for the colon (C). Each of the diets $x$ sites interactions examined, systematically, possible differences in effects of diets at the various intestinal sites. For example, $(\mathrm{B} v . \mathrm{P}) \times(\mathrm{D} v . \mathrm{I})$ tested whether the difference between + bran and + pectin differed between the duodenum and ileum. For selected variables, additional post hoc-nominated between-diet comparisons, i.e. $\mathrm{N} v . \mathrm{B}$ and $\mathrm{N} v$. $\mathrm{P}$, were also carried out. For Expt 2, values from incubations performed in the absence $(-\mathrm{O})$ 
Table 2. Expts 1 and 2. Partition of degrees of freedom in analysis of variance of experimental values

\begin{tabular}{|c|c|}
\hline Source of variation & $\mathrm{df}$ \\
\hline $\begin{array}{l}\text { Between diets } \\
\text { S } v .(\mathrm{N}+\mathbf{B}+\mathbf{P}) \\
\mathrm{N} v \cdot(\mathbf{B}+\mathrm{P}) \\
\mathrm{B} v \cdot \mathbf{P}\end{array}$ & $\begin{array}{l}3 \\
1 \\
1 \\
1\end{array}$ \\
\hline Between-animals within-diets (error 1) & $19(16)^{*}$ \\
\hline Main plots total & $22(19)^{*}$ \\
\hline $\begin{array}{l}\text { Between sites } \\
(\mathrm{D}+\mathrm{I}) v . \mathrm{C} \\
\mathrm{D} v \mathrm{I}\end{array}$ & $\begin{array}{l}2 \\
1 \\
1\end{array}$ \\
\hline $\begin{array}{l}\text { Diets } \times \text { sites interaction } \\
(\mathrm{S} v \cdot(\mathrm{N}+\mathrm{B}+\mathrm{P})) \times((\mathrm{D}+\mathrm{I}) v . \mathrm{C}) \\
(\mathrm{N} v \cdot(\mathrm{B}+\mathrm{P})) \times((\mathrm{D}+\mathrm{I}) v . \mathrm{C}) \\
(\mathrm{B} v \cdot \mathrm{P}) \times((\mathrm{D}+\mathrm{I}) v \cdot \mathrm{C}) \\
(\mathrm{S} v \cdot(\mathrm{N}+\mathrm{B}+\mathrm{P})) \times(\mathrm{D} v . \mathrm{I}) \\
(\mathrm{N} v \cdot(\mathrm{B}+\mathrm{P})) \times(\mathrm{D} v . \mathbf{I}) \\
(\mathrm{B} v \cdot \mathrm{P}) \times(\mathrm{D} v . \mathrm{I})\end{array}$ & $\begin{array}{l}6 \\
1 \\
1 \\
1 \\
1 \\
1 \\
1\end{array}$ \\
\hline Error 2 & $38(32)^{*}$ \\
\hline Grand total & $68(59)^{*}$ \\
\hline
\end{tabular}

S, stock; N, no fibre; B, +bran; P, + pectin; D, duodenum; I, ileum; C, colon.

* Values for Expt 2.

For interpretation of contrasts, see p. 153.

and presence $(+O)$ of ouabain and the difference between $-\mathrm{O}$ and $+\mathrm{O}$ values $(\mathrm{O}$ dep $)$ were analysed separately. Contrasts significant at $P<0.05$ or better are shown in tables and figures.

\section{RESULTS}

Animal health, growth and caecal characteristics

Apart from one rat on the + bran diet in Expt 1 which developed a lung tumour and was removed from the study, the rats remained healthy. In both experiments, rats given the semi-purified diet including pectin grew less well than the other rats (Table 3). Caecal weight (in absolute terms and relative to body-weight) was lowest for the no-fibre diet, increased only slightly with the inclusion of bran, was approximately twice as great for the stock-diet-fed rats and three to four times greater for the + pectin animals. Changes in caecal tissue weight with diet were similar to those for mass of the whole organ. Caecal pH was inversely related to caecal mass, with the hydrogen ion concentration ten times higher on the + pectin than on the no-fibre diet (Table 3 ).

\section{Expt 1}

In this initial experiment, rates of $\mathrm{Zn}$ transfer into everted gut sacs ranged from 6.4 to 16.8 $\mu \mathrm{g} / \mathrm{g}$ tissue DM per $30 \mathrm{~min}$ (Table 4). When considered across all intestinal sites, rates of $\mathrm{Zn}$ transfer were significantly $(P<0.01)$ greater with pectin as the NSP source than with bran. Sacs from + pectin animals also transported $\mathrm{Zn}$ faster $(P<0.05)$ than those from nofibre animals. There were no significant intestinal site effects, but there were significant $(P<0.01)$ sites $\times$ diets interactions due largely to the almost three times greater $\mathrm{Zn}$ transfer across colonic tissue with the + pectin diet than with the no-fibre diet (Table 4). 


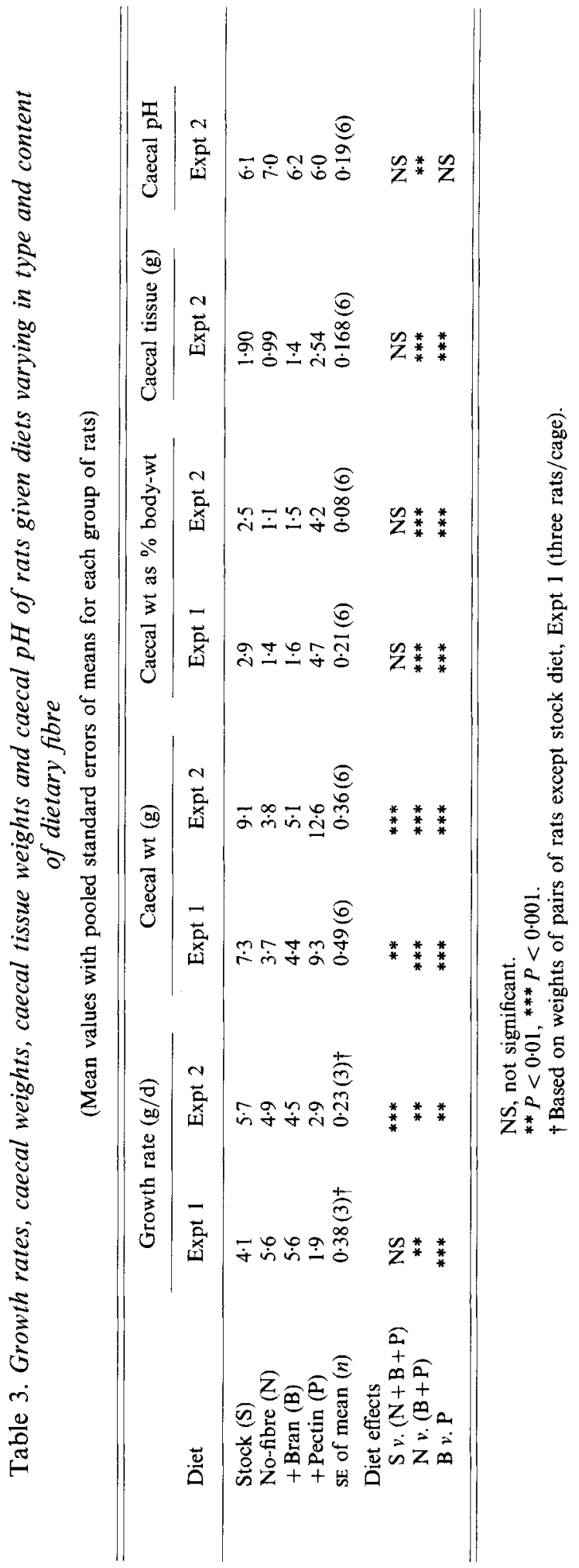


Table 4. Expt 1. Zinc transfer into everted gut sacs $(\mu \mathrm{g} \mathrm{Zn} / \mathrm{g}$ tissue dry matter per 30 min) from rats given ad lib. access to diets varying in content and type of dietary fibre*

(Each value is a mean from six animals except for + bran diet, where there were five animals)

\begin{tabular}{|c|c|c|c|c|}
\hline Diet... & Stock $(\mathrm{S})$ & No fibre (N) & $+\operatorname{Bran}(\mathbf{B})$ & $+\operatorname{Pectin}(\mathrm{P})$ \\
\hline Duodenum (D) & $7 \cdot 6$ & $8 \cdot 3$ & $9 \cdot 0$ & $8 \cdot 8$ \\
\hline Ileum (I) & $8 \cdot 6$ & $10 \cdot 5$ & 6.9 & $10 \cdot 2$ \\
\hline Colon (C) & $7 \cdot 2$ & $6 \cdot 4$ & $8 \cdot 7$ & 168 \\
\hline
\end{tabular}

Mean squares were 35.30 and 13.58 for error terms 1 and 2 respectively (for details of analysis of variance, see Table 2).

Significant effects: (1) between diets: B v. P; $P<0.05$; (2) sites $\times$ diets interaction: $((\mathrm{D}+\mathrm{I}) v . \mathrm{C}) \times(\mathrm{N} v$. $(\mathrm{B}+\mathrm{P})) P<0.001,((\mathrm{D}+\mathrm{I}) v . \mathrm{C}) \times(\mathrm{B} v . \mathrm{P}) P<0.01$.

* For details of diets, see p. 152 and Table 1.

Table 5. Expt 2. Zinc transfer into everted gut sacs ( $\mu \mathrm{g} \mathrm{Zn} / \mathrm{g}$ tissue dry matter per $30 \mathrm{~min}$ ) from rats given diets varying in content and type of dietary fibre $\dagger$ and where incubations were performed in the absence $(-O)$ and presence $(+O)$ of ouabain

(Each value is a mean for six animals except for + bran diet where there were four animals)

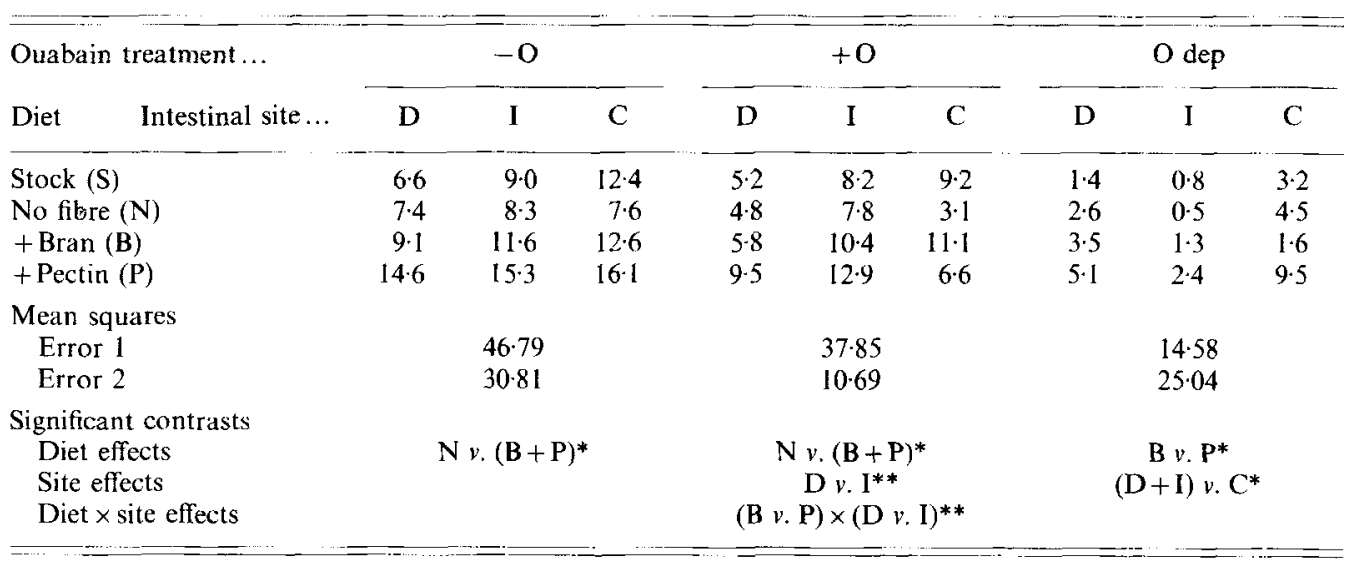

$\mathrm{O}$ dep, $\mathrm{Na}^{+}, \mathrm{K}^{+}$-ATPase-dependent transfer calculated as difference between $-\mathrm{O}$ and $+\mathrm{O}$ values; $\mathrm{D}$, duodenum; I, ileum; C, colon.

* $P<0.05, * * P<0.01$.

$\dagger$ For details of diets, see p. 152 and Table 1.

\section{Expt 2}

To ascertain the importance of energy-demanding $\mathrm{Na}^{+}, \mathrm{K}^{+}$-ATPase-dependent transfer by the intestinal everted sacs, incubations were carried out in the presence and absence of $0 \cdot 25$ mm-ouabain.

\section{Zn}

In the absence of ouabain, rates of $\mathrm{Zn}$ transfer by the everted gut sacs were similar to those found in Expt 1, ranging from 6.6 to $16.1 \mu \mathrm{g} / \mathrm{g}$ tissue DM per $30 \mathrm{~min}$ (Table 5). For all intestinal sites, rates were highest on the + pectin and lowest on the no-fibre diets with this difference significant at $P<0.01$. When considered across all diets, mean rates of $\mathrm{Zn}$ 
Table 6. Expt 2. Zinc content of unincubated gut tissue ( $\mu \mathrm{g} \mathrm{Zn} / \mathrm{g}$ tissue dry matter) from rats given diets varying in content and type of dietary fibre

(Each value is a mean for six animals except for + bran diet where there were four animals)

\begin{tabular}{lcccc}
\hline Diet ... & Stock (S) & No fibre (N) & + Bran (B) & + Pectin (P) \\
\hline Duodenum (D) & 123 & 96 & 93 & 106 \\
Ileum (I) & 208 & 212 & 149 & 195 \\
Colon (C) & 131 & 149 & 92 & 178 \\
\hline
\end{tabular}

Mean squares were 1921 and 1283 for error terms 1 and 2 respectively (for details of analysis of variance, see Table 2).

Significant effects: (1) diet effects: B v. P, $P<0.01$; (2) site effects: D v. I, $P<0.001$.

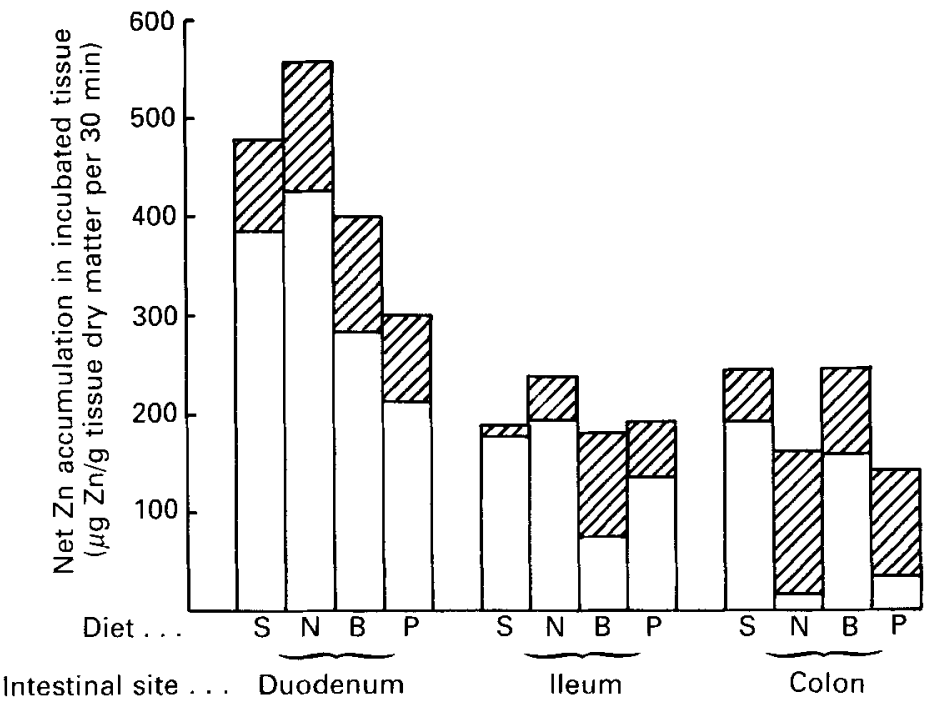

Fig. 1. The net accumulation after in vitro incubation of zinc in duodenal (D), ileal (I), and colonic (C) tissue from rats given diets varying in content and type of dietary fibre. Diets were stock (S), no fibre $(N)$, + bran $(B)$ and + pectin (P) (for details of diets, see p. 152 and Table 1). Incubations were performed in the presence $(\square ;+O)$ and absence $\left(\square+\square^{2}\right)$ of $0.25 \mathrm{~mm}$-ouabain with $\mathrm{Na}^{+}, \mathrm{K}^{+}$-ATPase-dependent accumulation (䀁; $O$ dep) calculated by difference. Each value is the mean for six animals except for + bran where there were four animals.

Statistical analysis (for details of analysis of variance, see Table 2)

\begin{tabular}{|c|c|c|c|}
\hline Ouabain treatment... & $-\mathrm{O}$ & $+\mathrm{O}$ & O dep \\
\hline $\begin{array}{l}\text { Mean squares } \\
\text { Error } 1 \\
\text { Error } 2\end{array}$ & $\begin{array}{l}23942 \\
23902\end{array}$ & $\begin{array}{l}26297 \\
17650\end{array}$ & $\begin{array}{l}10898 \\
13595\end{array}$ \\
\hline $\begin{array}{l}\text { Significant contrasts } \\
\text { Site effects } \\
\text { Diet } \times \text { site effects }\end{array}$ & $\begin{array}{c}(\mathrm{D}+\mathrm{I}) v \cdot \mathrm{C}^{* *} \\
\mathrm{D} v . \mathrm{I}^{* * *}\end{array}$ & $\begin{array}{c}(\mathrm{D}+\mathrm{I}) v \cdot \mathrm{C}^{* * *} \\
\mathbf{D} v \cdot \mathrm{I}^{* * *} \\
(\mathrm{~N} v \cdot(\mathrm{B}+\mathrm{P})) \times((\mathrm{D}+\mathrm{I}) v \cdot \mathrm{C})^{*}\end{array}$ & \\
\hline
\end{tabular}

$$
{ }^{*} P<0.05 ;{ }^{* *} P<0.01,{ }^{* *} P<0.001
$$




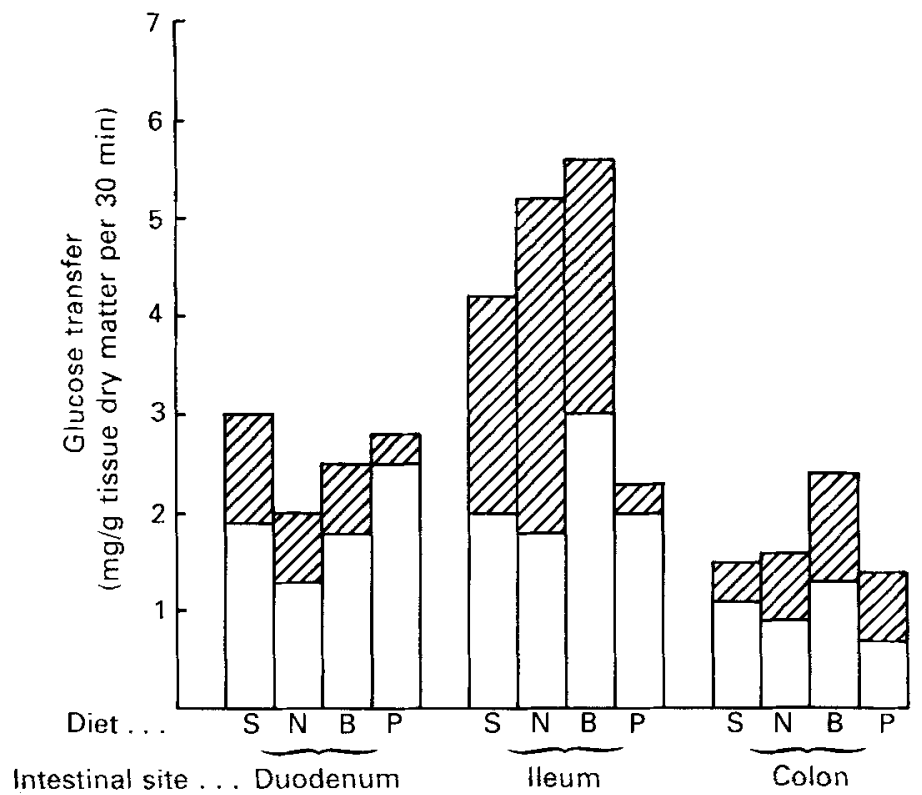

Fig. 2. Glucose transfer into everted gut sacs from rats given diets varying in content and type of dietary fibre. Sacs were prepared from duodenal (D), ileal (I) and colonic (C) tissue. Diets were stock (S), no fibre (N), + bran (B) and + pectin (P) (for details of diets, see p. 152 and Table 1). Incubations were performed in the presence ( $\square$;

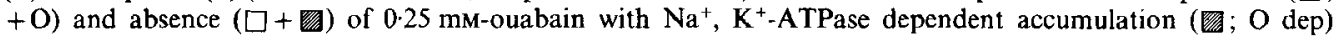
calculated by difference. Each value is the mean for six animals, except for + bran where there were four animals.

Statistical analysis (for details of analysis of variance, see Table 2)

\begin{tabular}{|c|c|c|c|}
\hline Ouabain treatment ... & $-\mathrm{O}$ & +0 & $O$ dep \\
\hline \multicolumn{4}{|l|}{ Mean squares } \\
\hline Error 1 & 17664 & 5387 & 14362 \\
\hline Error 2 & 23015 & 5123 & 19359 \\
\hline \multicolumn{4}{|l|}{ Significant contrasts } \\
\hline Diet effects & $\mathrm{B} v . \mathrm{P}^{*}$ & $\mathrm{~N} v \cdot(\mathrm{B}+\mathrm{P})^{*}$ & $\mathrm{~B}$ v. $\mathrm{P}^{*}$ \\
\hline Site effects & $\begin{array}{c}(\mathrm{D}+\mathbf{I}) v \cdot \mathrm{C}^{* * *} \\
\mathrm{D} v \cdot \mathbf{I}^{* *}\end{array}$ & $(\mathrm{D}+\mathrm{I}) v \cdot \mathrm{C}^{* *}$ & D y. I** \\
\hline Diet $\times$ site effects & $(\mathrm{B} v . \mathrm{P}) \times(\mathrm{D} v . \mathrm{I})^{*}$ & $(\mathrm{~B} v . \mathrm{P}) \times(\mathrm{D} v . \mathrm{I})^{*}$ & \\
\hline
\end{tabular}

transfer were $9 \cdot 4,11 \cdot 1$ and $12 \cdot 2 \mu \mathrm{g} / \mathrm{g}$ tissue DM per $30 \mathrm{~min}$ for duodenum, ileum and colon respectively. There were no significant site or diet $\times$ site effects.

When considered over all sites and diets, inclusion of ouabain in the incubation medium reduced rates of $\mathrm{Zn}$ transfer by $28 \%$, but the reduction was greater for the duodenum and colon (33 and $38 \%$ respectively) than for the ileum $(11 \%)$, indicating the reduced importance of $\mathrm{Na}^{+}, \mathrm{K}^{+}$-ATPase-dependent steps in $\mathrm{Zn}$ transfer by the terminal small intestine. In the presence of ouabain, $\mathrm{Zn}$ transfer was significantly $(P<0.05)$ higher by tissue from + pectin rats than from those on the no-fibre diet, and rates of transfer were greater $(P<0.01)$ by ileal than by duodenal tissue.

Rates of $\mathrm{Na}^{+}, \mathrm{K}^{+}$-ATPase-dependent $(\mathrm{O}$ dep) transfer of $\mathrm{Zn}$ were significantly $(P<0.05)$ higher for + pectin than for + bran or no-fibre rats and rates of transfer were greater for colonic than for duodenal and ileal tissue (Table 5) when considered across all diets. 
The $\mathrm{Zn}$ content of unincubated tissue from + bran-fed rats was significantly lower $(P<$ $0.01)$ than from those given the no-fibre or the + pectin diet, and was significantly $(P<$ 0.001 ) lower for duodenal tissue than for ileal tissue (Table 6). In the absence of ouabain, net accumulation of $\mathrm{Zn}$ by intestinal tissue (calculated as the difference between $\mathrm{Zn}$ content of unincubated and incubated tissue) was unaffected by diet, but was significantly $(P<$ $0.001)$ greater for duodenal than for ileal tissue, with accumulations by ileal and colonic tissue being similar (Fig. 1). Zn accumulation by $\mathrm{Na}^{+}, \mathrm{K}^{+}$-ATPase-independent routes $(+\mathrm{O})$ showed a similar pattern and was significantly $(P<0.001)$ greater for duodenal than for ileal tissue (Fig. 1). There were no significant $(P>0 \cdot 05)$ treatment effects on $\mathrm{Zn}$ accumulation by $\mathrm{Na}^{+}, \mathrm{K}^{+}-\mathrm{ATPase}-$ dependent $(\mathrm{O}$ dep) routes.

\section{Glucose}

Rates of glucose transfer by everted gut sacs were in the order ileum $>$ duodenum $>$ colon. Total glucose transfer and transfer by $\mathrm{Na}^{+}, \mathrm{K}^{+}$-ATPase-dependent routes were greater for tissue from rats given the bran-containing diet than that from those given the + pectin diet (Fig. 2). Over all sites and diets, inclusion of ouabain reduced the rate of glucose transfer by $41 \%$, but the effect was greater for the distal intestine (ileum and colon 49 and $42 \%$ respectively) than for the duodenum $(27 \%)$. When considered over all diets, $\mathrm{Na}^{+}, \mathrm{K}^{+}-$ ATPase-dependent glucose transfer rate by ileal tissue was approximately three times greater than that by either duodenal or colonic tissue, despite a low rate for ileal sacs from + pectin rats (Fig. 2). This contrasts with the relative unimportance of $\mathrm{Na}^{+}, \mathrm{K}^{+}$-ATPasedependent routes for $\mathrm{Zn}$ transfer by ileal tissue.

\section{DISCUSSION}

Following its development for measurement of sugar absorption (Wilson \& Wiseman, 1954), the everted-gut-sac procedure has been validated and used extensively for studies of intestinal uptake of several minerals (Aldor \& Moore, 1970; Arduser et al. 1985) including Zn (Pearson et al. 1966; Seal \& Heaton, 1983). In the present study, rates of mucosal : serosal transfer of both glucose and $\mathrm{Zn}$, and tissue accumulation of $\mathrm{Zn}$ were reduced by the inclusion of $0.25 \mathrm{~mm}$-ouabain in the incubation medium, indicating the presence of active, energy-demanding, $\mathrm{Na}^{+}, \mathrm{K}^{+}$-ATPase-dependent transport mechanisms in the gut preparation used. In addition, these tissue preparations showed differential responses in mucosal: serosal transfer for the two nutrients, with 0.45 of glucose but only 0.10 of $\mathrm{Zn}$ transfer by ileal tissue being $\mathrm{Na}^{+}, \mathrm{K}^{+}$-ATPase-dependent.

As used in the present study, the everted-gut-sac procedure is useful for investigation of treatment effects on the potential capacity of intestinal mucosa to take up $\mathrm{Zn}$ and to retain it within the tissue or to transfer it across the serosa. Changes in accumulation or transfer associated with different diets are, therefore, due to changes in the disposition of the mucosa induced by diet rather than to lumen events, since the gut segments were washed free of digesta before eversion and incubation.

\section{Tissue Zn concentrations}

Concentrations of $\mathrm{Zn}$ in intestinal tissue were higher in the ileum than in the duodenum or colon (Table 6) in confirmation of earlier reports by Ghishan \& Sobo (1983) and by Emes \& Arthur (1975). Since mucosal metallothionein concentrations are higher in the duodenum than in the ileum (Flanagan et al. 1983), it seems likely that other Zn-binding proteins may be more important in ileal tissue. 


\section{Sites of $\mathrm{Zn}$ absorption}

There were no significant differences in rates of $\mathrm{Zn}$ transfer by everted sacs from duodenal, ileal and colonic sites, but there was a tendency towards higher rates of transfer at more distal sites in both experiments. However, in agreement with the work of Kowarski et al. (1974), accumulation by intestinal tissue was a much more important fate for $\mathrm{Zn}$ removed from the incubation medium than was transfer across the serosal surface, and it should be noted that accumulation of $\mathrm{Zn}$ by sacs from the duodenum was approximately twice as great as that by tissue from either the ileum or colon. The form and location of $\mathrm{Zn}$ accumulated within gut tissue was not elucidated in the present study, but some may have been bound to metallothionein which occurs in higher concentrations in the duodenum than in the ileum (Flanagan et al. 1983) and to other Zn-binding proteins (Seal \& Heaton, 1987). Such binding appears to be important in regulation of $\mathrm{Zn}$ absorption (Cousins, 1986; Solomons, 1986) and in $\mathrm{Zn}$ transport across the brush border (Seal \& Heaton, 1987).

Higher rates of $\mathrm{Zn}$ transport or absorption by the colon or ileum, or both, than by the duodenum in rats have been reported by Kowarski et al. (1974), Emes \& Arthur (1975), Antonson et al. (1979), Meneely \& Ghishan (1982) and Wapnir et al. (1985), but this is in contrast to observations by Methfessel \& Spencer (1973), Davies (1980) and Seal \& Heaton (1983). Indeed, Davies (1980) reported that $60 \%$ of ${ }^{65} \mathrm{Zn}$ absorption occurred in the duodenum, with only negligible absorption from the caecum and colon. It is difficult to reconcile these disparate observations, but some of the differences may relate to the experimental technique, strain of rat or diet used. Our present observations, together with those demonstrating substantial absorption of $\mathrm{Zn}$ from the large bowel of other species (pigs: Partridge, 1978; sheep: Grace, 1975; cattle: Bertoni et al. 1976), suggest that this organ has the potential to absorb nutritionally important amounts of $\mathrm{Zn}$, but that this potential may not always be expressed. For example, the relatively small proportion of ${ }^{65} \mathrm{Zn}$ absorbed from the colon after installation into the caecum of patients undergoing colonscopy for evident or suspected polypoid adenoma may have been due to the preparative treatment of the bowel preceding colonscopy or to the prevailing ailment (Sandstrom et al. 1986).

\section{Effects of dietary fibre}

Contrary to earlier beliefs that NSP provided inert 'bulk' in the diet, it is now clear that NSP are fermented in the large bowel, resulting in important changes in the anatomy, physiology and biochemistry of the gut (Cummings, 1981, 1984) and may influence the metabolic activities of the enteric flora (Wyatt et al. 1986; Cheng et al. 1987; Key \& Mathers, 1987). The concentrations of NSP ( $\mathrm{g} / \mathrm{kg}$ diet) in the diets used in the present study were stock 187, no fibre $0,+$ bran 74 and + pectin 200 . When compared with animals given the NSP-free no-fibre diet, there was substantial hypertrophy of the caecum and a reduction in $\mathrm{pH}$ with the + pectin, stock and, to a lesser extent, + bran diets, indicating that these diets promoted microbial fermentation in this organ (Table 3).

Changes in total caecal weight were accompanied by changes in caecal tissue weight. Wyatt et al. (1988) reported that the extent of hypertrophy of the rat caecum in response to dietary inclusion of NSP differed for different NSP sources. Whilst the reasons for these differences were unclear, Wyatt et al. (1988) observed a close quadratic relation between caecal contents and caecal tissue masses. Using the equation of Wyatt et al. (1988) and the caecal contents masses observed in the present study, the caecal tissue masses predicted for animals given the stock, no-fibre, + bran and + pectin diets were $1.8,0.9,1.0$ and $2.4 \mathrm{~g}$ respectively, which are in fair agreement with our observed findings in Table 3 . In the present study, higher dietary NSP concentrations were associated with greater caecal masses. 
Very little is known about the effects of stimulation of large bowel fermentation on mineral absorption. In a feeding trial with healthy male students, Cummings et al. (1979) observed that pectin which binds $\mathrm{Ca}$ in vitro had no effect on $\mathrm{Ca}$ balance. Whilst pectin is not digested by mammalian enzymes, it is very readily fermented by the large-bowel flora (Goodlad \& Mathers, 1988), and Cummings et al. (1979) speculated that Ca bound to pectin and carried to the large bowel may have been released therein and absorbed from this organ when this NSP source was fermented. The large bowel of both rats (Ammann et al. 1986) and man (Sandstrom et al. 1986) has the potential for Ca absorption, and rats adapted to a diet rich in fermentable NSP absorbed twice as much Ca from the caecum as did those given a fibre-free diet (Demigne \& Remesey, 1985).

In the present study, the highest rates of Zn transfer were those by colonic tissue from + pectin rats (Tables 4 and 5), whilst tissue from animals given diets containing lessfermentable NSP (stock and + bran) resulted in slightly higher $\mathrm{Zn}$ transfer rates than the no-fibre diet in both experiments. Rats given the + pectin diet grew least quickly, and it might be anticipated that reduced growth would be accompanied by reduced rates of $\mathrm{Zn}$ transfer, but the opposite effect was observed in the present study. There is evidence that giving pectin (but not wheat bran) may produce ultrastructural modifications of colonic mucosa (Vahouny et al. 1981), but other fermentable NSP sources which also cause caecal enlargement did not alter gut morphology (Anderson et al. 1986). The functional significance of any morphological changes in mucosa with pectin feeding are unclear, but Shiau \& Chang (1986) observed reduced apparent permeability of the intestine in pectinfed rats which suggests that the increased potential for $\mathrm{Zn}$ absorption by colonic tissue observed in the present study is unlikely to be due to a general increase in 'leakiness' of the mucosa.

Inclusion of pectin in the diet of rats may increase the length of the small intestine (J. C. Mathers and H. J. Finlayson, unpublished results) and increase the weight of mucosa per unit length (Brown et al. 1979), with the latter effect a possible consequence of increased epithelial proliferation rate (Jacobs, 1983). Increased $\mathrm{Zn}$ transport rates observed in the present study might, therefore, be a result of greater mucosal mass per unit weight of intestine. Such measurements were not made in our study, but the findings of Brown et al. (1979) indicate little effect of dietary pectin in this regard, with mucosal wet weight as a proportion of total intestinal wet weight for rats given basal (no NSP) and pectincontaining diets being 0.46 and $0.53,0.45$ and 0.47 and 0.37 and 0.35 for upper jejunal, midjejunal and ileal tissue respectively. It, therefore, seems unlikely that by expressing our transfer values per unit total tissue DM (rather than mucosa weight), we have obscured possible dietary effects, but further studies of this area and especially of the colon are warranted.

In conclusion, the present study has demonstrated that the colon appears to have considerable capacity to absorb $\mathrm{Zn}$ by $\mathrm{Na}^{+}, \mathrm{K}^{+}$-ATPase-dependent mechanisms and that this capacity may be enhanced by consumption of pectin, a source of fermentation NSP.

The authors thank E. Atkinson for his assistance with Expt 1 and R. Henderson, Department of Statistics for advice on statistical analysis.

\section{REFERENCES}

Aldor, T. A. M. \& Moore, E. W. (1970). Magnesium absorption by everted sacs of rat intestine and colon. Gastroenterology 59, 745-753.

Ammann, P., Rizzoli, R. \& Fleisch, H. (1986). Calcium absorption in the rat large intestine in vivo: availability of dietary calcium. American Journal of Physiology 251, G14 G18. 
Anderson, D. M. W., Busuttil, A., Kempson, S. A. \& Penman, D. W. (1986). Transmission electron microscopy of jejunum, ileum, and caecum tissue from rats fed with gum arabic, karaya and tragacanth. Toxicology 41, $75-82$.

Antonson, D. L., Barak, A. J. \& Vanderhoof, J. A. (1979). Determination of the site of zinc absorption in rat small intestine. Journal of Nutrition 109, 142-147.

Arduser, F., Wolffram, S. \& Scharrer, E. (1985). Active absorption of selenate by rat ileum. Journal of Nutrition 115, 1203-1208.

Bertoni, G., Watson, M. J., Savage, G. P. \& Armstrong, D. G. (1976). The movements of minerals in the digestive tract of dry and lactating Jersey cows. 2. Net movements of $\mathrm{Cu}, \mathrm{Fe}, \mathrm{Mn}$ and $\mathrm{Zn}$. Zootecnica e Nutrizione Animale 11, 185-191.

Brown, R. C., Kelleher, J. \& Losowsky, M. S. (1979). The effect of pectin on the structure and function of the rat small intestine. British Journal of Nutrition 42, 357-365.

Cheng, B.-Q., Trimble, R. P., Illman, P. J., Stone, B. A. \& Topping, D. L. (1987). Comparative effects of dietary wheat bran and its morphological components (aleurone and pericarp-seed coat) on volatile fatty acid concentrations in the rat. British Journal of Nutrition 57, 69-76.

Cousins, R. J. (1986). Zinc metabolism-coordinate regulation as related to cellular function. In Proceedings of the XIII International Congress of Nutrition, pp. $500-504$ [T. G. Taylor and N. K. Jenkins, editors]. London: John Libbey.

Cummings, J. H. (1981). Dietary fibre. British Medical Bulletin 37, 65-70.

Cummings, J. H. (1984). Constipation, dietary fibre and the control of large bowel function. Postgraduate Medical Journal 60, $811-819$.

Cummings, J. H., Southgate, D. A. T., Branch, W. J., Wiggins, H. S., Houston, H., Jenkins, D. J. A., Jivraj, T. \& Hill, M. J. (1979). The digestion of pectin in the human gut and its effects on calcium absorption and large bowel function. British Joumal of Nutrition 41, 477-485.

Davies, N. T. (1980). Studies on the absorption of zinc by rat intestine. British Journal of Nutrition 43, $189-203$.

Davies, N. T. \& Nightingale, R. (1975). The effects of phytate on intestinal absorption and secretion of zinc and whole body retention of zinc, copper, iron and manganese in rats. British Journal of Nutrition 34, 243-258.

Davies, N. T. \& Reid, H. (1979). An evaluation of the phytate, zinc, copper, iron and manganese contents of, and $\mathrm{Zn}$ availability from, soya-based textured-vegetable-protein meat-substitutes or meat-extenders. British Journal of Nutrition 41, 579-589.

Demigne, C. \& Remesey, C. (1985). Stimulation of absorption of volatile fatty acids and minerals in the caecum of rats adapted to a very high fibre diet. Journal of Nutrition 115, 53-60.

Emes, J. H. \& Arthur, D. (1975). The site of zinc absorption in the rat small intestine. Proceedings of the Society for Experimental Biology and Medicine 148, 86-88.

Englyst, H. N. \& Cummings, J. H. (1984). Simplified method for the measurement of total non-starch polysaccharides by gas-liquid chromatography of constituent sugars as alditol acetates. Analyst 109, $937-942$.

Englyst, H. N. \& Cummings, J. H. (1985). Digestion of the polysaccharides of some cereal foods in the human small intestine. American Journal of Clinical Nutrition 42, 778-787.

Evans, G. W., Grace, C. I. \& Hahn, C. (1973). Homeostatic regulation of zinc absorption in the rat. Proceedings of the Society for Experimental Biology and Medicine 143, 723-725.

Evans, G. W. \& Johnson, E. C. (1981). Effect of iron, vitamin B6 and picolinic acid on zinc absorption in the rat. Journal of Nutrition 111, 68-75.

Fairweather-Tait, S. J. \& Wright, A. J. A. (1985). The effect of 'fibre-filler' (F-plan diet) on iron, zinc and calcium absorption in rats. British Journal of Nutrition 54, 585-592.

Flanagan, P. R., Haist, J.\& Valberg, L. S. (1983). Zinc absorption, intraluminal zinc and intestinal metallothionein levels in zinc-deficient and zinc-replete rodents. Journal of Nutrition 113, 962-972.

Ghishan, F. K. \& Sobo, G. (1983). Intestinal maturation: in vivo zinc transport. Pediatric Research 17, 148-151,

Goodlad, J. S. \& Mathers, J. C. (1988). Effects of food carbohydrates on large intestinal fermentation in vitro. Proceedings of the Nutrition Society 47, 176A.

Grace, N. D. (1975). Studies on the flow of zinc, cobalt, copper and manganese along the digestive tract of sheep given perennial ryegrass, or white or red clover. British Journal of Nutrition 34, 73-82.

Hoadley, J. E., Leinart, A. S. \& Cousins, R. J. (1987). Kinetic analysis of zinc uptake and serosal transfer by vascularly perfused rat intestine. American Journal of Physiology 252, G825-G831.

Jacobs, L. R. (1983). Modulation of mucosal cell proliferation in the intestine of rats fed a wheat bran diet. American Journal of Clinical Nutrition 37, 954-960.

James, W. P. T., Branch, W. J. \& Southgate, D. A. T. (1978). Calcium binding by dietary fibre. Lancet i, 638.

Key, F. B. \& Mathers, J. C. (1987). Response of rat caecal metabolism to varying proportions of white and wholemeal bread. Proceedings of the Nutrition Society 46, $11 \mathrm{~A}$.

Kowarski, S., Blair-Stanek, C. S. \& Schachter, D. (1974). Active transport of zinc and identification of zincbinding proteins in rat jejunal mucosa. American Journal of Physiology 226, 401-407.

Lonnerdal, B., Stanislowski, A. G. \& Hurley, L. S. (1980). Isolation of a low molecular weight zinc binding ligand from human milk. Journal of Inorganic Biochemistry 12, 71-78. 
McCance, R. A. \& Widdowson, E. M. (1942a). Mineral metabolism of healthy adults on white and brown bread dietaries. Journal of Physiology 101, 44-85.

McCance, R. A. \& Widdowson, E. M. (1942b). Mineral metabolism on dephytinised bread. Journal of Physiology 101, 304-313.

Meneely, R. \& Ghishan, F. K. (1982). In vivo intestinal zinc transport in rats: normal and growth retarded. Journal of Pediatric Gastroenterology and Nutrition 1, 119-124.

Methfessel, A. H. \& Spencer, H. (1973). Zinc metabolism in the rat. Intestinal absorption of zinc. Journal of Applied Physiology 34, 58-62.

Oberleas, D., Muhrer, M. E. \& O'Dell, B. L. (1966). Dietary metal-complexing agents and zinc availability in the rat. Journal of Nutrition $90,56-62$.

O'Dell, B. L. \& Savage, J. E. (1960). Effect of phytic acid on zinc availability. Proceedings of the Society for Experimental Biology and Medicine 103, 304-306.

Partridge, I. G. (1978). Studies on digestion and absorption in the intestines of growing pigs. 4. Effects of dietary cellulose and sodium levels on mineral absorption. British Journal of Nutrition 39, 539-545.

Pearson, W. N., Schwink, T. \& Reich, M. (1966). In vitro studies on zinc in the rat. In Zinc Metabolism, pp. 239-249 [A. S. Prasad, editor]. Springfield, Illinois: C. C. Thomas.

Sandstrom, B., Cederblad, A., Kivisto, B., Stenquist, B. \& Andersson, H. (1986). Retention of zinc and calcium from the human colon. American Journal of Clinical Nutrition 44, 501-504.

Schiau, S.-Y. \& Chang, G. W. (1986). Effects of certain dietary fibres on apparent permeability of the rat intestine. Journal of Nutrition 116, 223-232.

Seal, C. J. \& Heaton, F. W. (1983). Chemical factors affecting the intestinal absorption of zinc in vitro and in vivo. British Journal of Nutrition 50, 317-324.

Seal, C. J. \& Heaton, F. W. (1985). Effect of dietary picolinic acid on the metabolism of exogenous and endogenous zinc in the rat. Journal of Nutrition 115, 986-993.

Seal, C. J. \& Heaton, F. W. (1987). Zinc transfer among proteins in rat duodenal mucosa. Annals of Nutrition and Metabolism 31, 55-60.

Seal, C. J. \& Mathers, J. C. (1987). $\mathrm{Na}^{+}-\mathrm{K}^{+}$-ATPase-dependent zinc transfer by everted gut sacs from rats given different amounts and types of dietary fibre. Proceedings of the Nutrition Society 46, 54A.

Solomons, N. W. (1986). Zinc bioavailability to humans. In Proceedings of the XIII International Congress of Nutrition, pp. 504-508. [T. G. Taylor and N. K. Jenkins, editors]. London: John Libbey.

Underwood, E. J. (1977). Zinc. In Trace Elements in Human and Animal Nutrition, 4th ed. New York: Academic Press.

Vahouny, G. V., Cassidy, M. M., Lightfoot, F., Grau, L. \& Kritchevsky, D. (1981). Ultrastructural modifications of intestinal and colonic mucosa induced by free or bound bile acids. Cancer Research 41, 3764-3765.

Wapnir, R. A., Garcia-Aranda, J. A., Mevorach, E. K. \& Lifshitz, F. (1985). Differential absorption of zinc and low molecular weight ligands in the rat gut in protein-energy malnutrition. Journal of Nutrition 115, 900-908.

Wilson, T. H. \& Wiseman, G. (1954). The use of sacs of everted small intestine for the study of the transference of substances from the mucosal to the serosal surface. Journal of Physiology 123, 116-125.

Wise, A. (1983). Dietary factors determining the biological activities of phytate. Nutrition Abstracts and Reviews 53, 791-806.

Wyatt, G. M., Bayliss, C. E. \& Holcroft, J. D. A. (1986). A change in human faecal flora in response to inclusion of gum arabic in the diet. British Journal of Nutrition 55, 261-266.

Wyatt, G. M., Horn, N., Gee, J. M. \& Johnson, I. T. (1988). Intestinal microflora and gastrointestinal adaptation in the rat in response to non-digestible dietary polysaccharides. British Journal of Nutrition 60, 197-207. 